how other aspects of the project were developing in accordance with the programme of the Indian Government.

Sir Willis Jackson, as chairman of the Technical Sub-Committee of the Trust, referred to the difficulties at the present time of finding the right calibre of man for professorial posts. He emphasized the need for further help by British industry, perhaps by endowing chairs at the College, and also by facilitating the secondment of experts in specialist fields of technology for short periods to assist in the conduct of postgraduate courses and in stimulating research.

Sir Algernon Rombold, Deputy Under-Secretary of State, Commonwealth Relations Office, said that satisfaction at the response to the sponsors' appeal would be widely shared, and that the project was an outstanding example of co-operation between the Governments of India and the United Kingdom and
British industry. He endorsed the hope that a recognized system of secondment by industry and universities would be developed to meet the growing need for experts for overseas service.

Sir Alexander Fleck said that the vigour of the work of the Trust's officers showed that the special problems presented by any tripartite project of this nature were being solved in a satisfactory way. $\mathrm{He}_{e}$ believed that the continued support of British industry would be readily forthcoming for the project on the lines which Sir William McFadzean had sketched out. This would be true both in the immediate future and over the years as the project developed.

Among the other sponsors present were Sir Hugh Beaver, Sir Leslie Gamage, Mr. S. E. Goodall, Sir Kenneth Hague, Sir Harry Jephcott, Prof. Sutton Pippard and Mr. Whitney Straight. Other sponsors who were unable to attend were represented.

\title{
THE ROBERTSON CREEK SPAWNING CHANNEL
}

$\mathrm{M}$ UCH of a recent issue of the Canadian Fish Culturist (No. 27, 1960) is given up to accounts by $K$. C. Lucas and D. Mackinnon of a man-made spawning channel which has just been built by the Fish Culture Development Branch of the Department of Fisheries of Canada in Robertson Creek. This is a secondary outlet of Great Central Lake, which lies near Port Alberni on Vancouver Island, British Columbia.

The design of this new artificial spawning channel is based on the experience gained in the construction and operation of an artificial spawning channel on Jones Creek, near Hope, British Columbia, which was made in 1954. The Jones Creek channel was constructed to save the salmon stocks in a stream threatened by the diversion of the flow because of hydro-electric development, but the Robertson Creek channel is the first such channel to be built primarily as a fisheries development project. Robertson Creek is an exceptionally favourable area for such a project, because works for the complete control of flows already existed, no provision for flood-flows was necessary, silting of the spawning beds by the incoming water seemed unlikely, the temperature of the stream remained moderate and the area was readily accessible.

The total length of Robertson Creek is 4,200 ft., and $2,550 \mathrm{ft}$. have been developed as a spawning channel. The gradient of the natural stream bed was greater than that needed for the spawning channel, so four drop-structures have been provided to localize the unwanted drop. Near the head of the spawning channel and a short distance below Great Central Lake is a downstream migrant diversion structure, which allows migrants passing out of Great Central Lake to be diverted into a flume which runs alongside the spawning channel to enter the latter just below drop strueture 3 . If it were found necessary in the future, this diversion flume could be extended downstream so as to bypass the lower spawning area. The first three drop-structures downstream from the diversion structure are similar in design and are relatively simple structures. Inclined plane traps are provided at each so that downstream migrants can be counted, and each incorporates a pool and weir-type fishway to provide for the upstream movements of adults if desired The lowermost drop-structure (4) is larger and more complex, because it incorporates a fish holding and collection system, and there is an observation chamber built into the side of the fishway.

A number of rearing ponds have been built at one side of the channel near its upper end, and these have been specially designed to allow maximum flexibility. Another additional structure is of par. ticular interest; this is an experimental test-flume, approximately $150 \mathrm{ft}$. long and $30 \mathrm{ft}$. wide, which lies in the channel a short distance below drop structure 3. Plans were made to construct this flume before it was decided to make the channel, and the Fisheries Research Board of Canada has contributed to its cost. This flume will be used for tests of fry and smolt guiding devices and for funda. mental work on the physiology of adult salmon.

Previous work on the survival of Pacific salmon eggs and alevins has shown that the percentage survival varies widely, but is usually low (less than 10 per cent). The results of the first transplant of pink salmon eggs in the Robertson Creek spawning channel are therefore particularly encouraging More than one and a half million pink salmon were planted, at the eyed stage, during the latter half of November and the first days of December 1959. The first fry was trapped on March 15, 1960, but nearly all the fry migrated during the first three weeks of April and, when the last batch recorded migrated, during the night of April 21-22, the total represented roughly 95 per cent of the eyed eggs planted.

This artificial spawning channel is clearly a very important site for experimental investigations of many aspects of the biology of various stages in the life-history of Pacific salmon. Judged as a piece of experimental equipment, it is not cheap. To date, more than $£ 81,000$ has been spent on the channel, the experimental flume and the small field camp which has been built near the lower end of the channel. T.t is becoming increasingly clear, however, that many problems of salmon biology cannot be solved unless adequate experimental facilities can be provided, and there is good reason to suppose, therefore, that this outlay will prove to be money well spent. 